\title{
Editorial 2015/X/3
}

\section{Jana Dlouhá}

Envigogika 10 (3) - Úvodník/Editorial

Publikováno/Published dne 31. 12. 2015

DOI: $10.14712 / 18023061.511$

Vážení naši čtenáři,

Nové číslo Envigogiky otevírá dvě témata: co znamená celostní pohled na vzdělávání, a jak prosadit svobodu jedince $v$ rámci procesu učení (a ve vztahu $k$ autoritě učitele). První téma vychází z tradičních základů pedagogiky tradovaných již od Jana Amose Komenského (1592-1670) a Johanna Heinricha Pestalozziho (1746-1827), na které později navázal Patrick Geddes. V jeho pojetí je úkolem vzdělání působit na celkový rozvoj osobnosti, včetně oblasti afektivní a fyzické (learning via the three Hs: Heart, Hand and Head) (Higgins, 2009) - na rozdíl od (tehdejší) běžné vzdělávací praxe víceméně potlačující smysly a emoce (learning with three Rs: Reading, wRiting, aRitmetic). Holistický prístup postavil dokonce proti abstraktním modelům zkušenostního učení, napríklad využívajících Kolbův cyklus: ty totiž nejsou zasazeny do př́mých souvislostí s lidskými hodnotami. Patrick Geddes usiloval o reformu vzdělávání, která by přinesla syntézu stávajících znalostí; především tak chtěl podpořit tvořivost v myšlení i praktické činnosti (Higgins, Nicol, 2011).

O podobně založeném „učení se ve skutečném světě" (program Real World Learning) diskutuje v tomto čísle Envigogiky více autorů: Jan Činčera jej představuje jako príležitost $\mathrm{k}$ novému pohledu na problematiku hodnot a rámců $\mathrm{v}$ outdoorové environmentální výchově, na což reaguje Lewis Winks svou polemikou s teoretickými východisky tzv. "modelu ruky", který je hlavním nástrojem pro plánování a hodnocení tohoto typu výchovy. Způsoby využití modelu pro hodnocení pobytového programu environmentální výchovy ukazuje opět Jan Činčera - př́nosem je možnost analyzovat proces učení $i$ jeho dílčí aspekty $v$ rámci navržených kategorií. $O$ tom, jak vnímat svět prostřednictvím smyslů - a také o tom adekvátně hovořit pomocí nových jazykových forem - pak pojednává recenze Lubov Vladykové: věnuje se nedávno přeložené práci Davida Abrama.

Druhé téma navozuje spiše jen jeden text tohoto čísla, který se týká názorové svobody jedince $v$ okolnostech výchovy. Kde je hranice mezi vedením a vyváděním (educare, educere), což je první a zásadní výchovný úkol, a kde začíná manipulace, o tom se vedou vášnivé debaty - týkají se vztahu mezi normativní povahou vzdělávání, a jejím instrumentálním zjednodušením $\vee$ praxi (srov. Wals, 2009). $\vee$ tomto čísle Envigogiky se této otázce věnují autoři Bohuslav Binka, Jan Činčera a Martin Černý, kteří ukazují model RWL ve světle Schwartzovy teorie hodnot; docházejí k závěrům o potřebě kritické sebereflexe učitele. Jak už to bývá, téma svobody prosvítá $\mathrm{i} v$ dalších publikovaných textech, například když jiř́ Kmínek představuje svůj program přirozeně a přirodně vedené výchovy chudých peruánských dětí, který přes (anebo možná právě pro) nedostatek formalizovaných postupů může mít velký dopad na samotné děti i místní komunitu.

Zde se vracíme zpět k tématu prvnímu: „holisticky" je založen i koncept kompetencí jakožto důležitých výsledků, ale i předpokladů učení - takto je analyzován u vysokoškolských 
učitelů $v$ regionu střední a východní Evropy $\underline{v}$ jednom $z$ dalších $z$ článků. A přehled tohoto čísla uzavíráme poukazem k "celkovému" smyslu a směřování lidského života, jak o něm uvažují Mark Hickman, Colin Beard a Alison Inkster. Jejich text na téma proměny vztahu (horolezců) k prírodním místům v průběhu dlouhých let jejich aktivního sportování ukazuje mimo jiné, že "osvobozujíci" působení prírody v tomto autentickém vztahu bývá často doceněno až po letech, $v$ perspektivě hodnocení celé životní cesty.

Abyste při veškerém svém konání měli na paměti tento smysl již od samého počátku, vám prejí editoři a redaktoři tohoto čísla Envigogiky

Jana Dlouhá

Další zdroje informací:

- Higgins, P. (2001c). Student outcomes: Learning with heart, hand and head. In A. Nilsson (Ed.), Outdoor education: Authentic learning in the context of landscapes Volume 1 (pp. 10-12). Sweden: Kinda Kunskapscentrum.

- Higgins, P., \& Nicol, R. (Eds.). (2002). Outdoor education: Authentic learning in the context of landscapes (Vol. 2). Sweden: Kinda Kunskapscentrum. 93p

- Higgins, P. (2009). Into the big wide world: Sustainable experiential education for the 21st century. Journal of Experiential Education, 32(1), 44-60.

- Higgins, P. \& Nicol, R. (2011). Professor Sir Patrick Geddes: "Vivendo Discimus" by living we learn. In C. Knapp \& T. Smith (Eds.), A sourcebook for experiential education: key thinkers and their contributions (pp. 32-40). New York: Routledge. (Draft copy attached - I don't have a pdf of the final version).

- Arjen E.J. Wals (2010) Between knowing what is right and knowing that is it wrong to tell others what is right: on relativism, uncertainty and democracy in environmental and sustainability education, Environmental Education Research, 16:1, 143-151, DOI: $10.1080 / 13504620903504099$ 